\title{
MYSTICAL UNION IN JUDAISM, CHRISTIANITY AND ISLAM
}

\author{
PhD. Alexandru-Corneliu ARION \\ Lecturer, Faculty of Theology and Sciences of Education, \\ "Valahia" University of Târgovişte, ROMANIA \\ Email: alexcoarion@yahoo.co.uk
}

Motto: «Theologians may quarrel, but the mystics of the world speak the same language». (Meister Eckhart)

\begin{abstract}
This article presents the so-often discussed problem of the core of religions, of what seems to link them rather than to separate them. Thus, after having presented the characteristics of unitive mysticism and its language at a phenomenological level, we turn to mystical union in the three major monotheistic religions of the world. Judaism, Christianity and even Islam have all developed the idea of a personal God, this ideal representing religion at its best. In the monotheistic faiths the God of creation, revelation, and redemption is not a static and indifferent First Principle but a loving and all-knowing God, who creates humans whose likeness to Him consists precisely in their ability to know and to love. However, the variations found in Judaism, Christianity, and Islam on this topic are too multiple to be easily characterized. That's why it is difficult to appreciate the dynamics of union unless one addresses the relation between unitive expressions and the roles of love and knowledge. Union, whether conceived of as the uniting of God and human or in a deeper way as some form of identity with God, has been a key feature of the mystical traditions of Judaism, Christianity, and Islam. Most mystics claim that both knowing and loving are necessary in the way to God, but many mystics stress the superiority of love, often expressed in highly erotic ways, whereas others conceive of union as attaining mental identity with the Divine Intellect. They make use of a variety of images and symbols, as well as distinctive expressions and forms of technical discourse, in their attempts to suggest through language what lies beyond language: the 'ineffable' God.
\end{abstract}

Keywords: mystical union, Judaism, Christianity, Islam, God, person, identity, love.

\section{INTRODUCTION}

In an era fully marked by the hegemony of empirical world, of what we know only through what our senses perceive, of what seem to many people a matter of common sense, the perceptual world, the world that we perceive with our five senses, is the only world that exists. Simple as these statements appear to be, they have formed the basis of great metaphysical problems. How can we know, it is asked, that which is outside our experience? But then what do we mean by "experience"? And why should the knowledge of our senses contain the whole of our experience?

On the other hand it is contended that the data given by the senses about reality are not valid as it is so strongly influenced by the nature of man and by his perceptual equipment and by his techniques of perception. The mystic believes that by means of special training he 
can so discipline, tune, and train his total organism that will be able to transcend these limitations and perceive reality more accurately. ${ }^{1}$

Leaving outside the mystical experiences from non-Judeo-Christian Tradition, we can start by showing the hardship to describe the nature of mystical union in the three monotheistic faiths is a task fraught with difficulties and ambiguities both conceptual and real. First, the term unio mystica is primarily a modern expression; though the phrase does occur in Christian mysticism, its appearance is relatively rare. Various words for and descriptions of union or uniting with God, however, are important in the history of Christian mysticism, and accounts of union with God are also prominent in Judaism and Islam.

Second, even the term mysticism itself, another modern creation, has come under attack. To what extent, for example, does the use of a term created in the modern Christian West distort the meaning of key figures, movements, and texts from the traditions of Judaism and Islam? The question is a real one, but the position adopted here is that, if mysticism is understood broadly as the preparation for, the consciousness of, and the effect engendered by what mystics describe as a direct and immediate transformative contact with the divine presence, then it is useful to speak of a strong mystical element in each of the three faiths.

Third, if one allows that mysticism is a helpful term in the study of religion, is mystical union to be conceived of as its essence? Though some investigators have so claimed, the study of mystical traditions indicates that the language of union is only one of the linguistic strategies used by mystics to try to describe, or at least to point to, what they contend is the ultimately ineffable nature of their contact with God. Unitive mysticism is one of a group of interactive and nonexclusive semantic fields found in the traditions of Judaism, Christianity, and Islam. There are mystics in each tradition who either explicitly avoid union language (e.g., Augustine of Hippo) or else who tend to relegate such language to the margin in favor of other modes of mystical expression, such as those related to the vision of God or to theurgical action in the divine realm. ${ }^{2}$

\section{CHARACTERISTICS OF UNITIVE MYSTICISM AND ITS LANGUAGE}

Definition: Mysticism is an umbrella concept for (1) experiences in which boundaries are dissolved - those of the subject, such as in a vacuum of thought, or in ecstasy; those of the object, so that dualities are removed; those of space, to experience the infinite in the finite; those of time, when the 'timeless, everlasting now' replaces successive time. 'Mysticism' also denotes (2) the concepts, teachings, and literary genres that contemplate, recount, or describe this immanent transcendence, or transcendent immanence. The intensity and quality of the experience are dependent on whether the transcendence in question is unprepared, and occurs spontaneously, or whether it is induced by techniques; on whether it occurs punctually, regularly, or permanently; on whether it is perceived purely mentally, or expresses itself in strong affects; on whether it is accompanied by (para-) sensory phenomena, such as visions, or even psychosomatic alterations, including permanent marks on the body, like stigmata. ${ }^{3}$

\footnotetext{
${ }^{1}$ E. M. AbRAHAms, A comparative survey of Hindu, Christian \& Jewish Mysticism, Sri Satguru Publications, Indological and Oriental Publishers, a Division of Indian Books Centre, Delhi, India, 1995, p. XV.

${ }^{2}$ Michel DupuY, "L'union a Dieu", in: Dictionnaire de spiritualite: Ascetique et mystique, doctrine et histoire, edited by Marcel Viller et al., vol. 16, cols. 40-61. Paris, 1992. A survey of Christian materials.

3 Annette WILKE, "Mysticism", in: The Brill Dictionary of Religion, edited by Kocku von STUCKRAD, Revised edition of Metzler Lexikon Religion, edited by Christoph Auffarth, Jutta Bernard and Hubert Mohr, transl. from the German by Robert R. Barr, Koninklijke Brill NV, Leiden, Boston, 2006, p. 1279.
} 
Treatments of mystical union have often employed the terms pantheism and monism to characterize unitive expressions, but pantheism and monism are not adequate categories for discerning the import of unitive language. God is certainly all things in the monotheistic faiths, in the sense that the world is a manifestation of God; but God is also transcendentally more than the world, so the simple identification between God and world implied in pantheism is not an accurate term. Monism, understood as the belief that there is one basic principle underlying all reality, is true of most forms of mysticism of the monotheistic religions (though not of Qabbalah). But monism tells little more than this and hence is an empty category for serious investigation of mysticism ${ }^{4}$. Previous scholarship on mysticism often employed oppositional terminology, such as impersonal versus personal union, absorptive versus non-absorptive union, habitual versus ecstatic union, essential union versus intentional union, and the like. Such typologizing, however, should not be applied in any crude way, as if mystics could easily be pigeonholed into one or the other category. The comparative dimensions of mystical union emerge from attention to some of the profound issues at work in unitive texts. ${ }^{5}$ The persistence across traditions of particular doctrinal and ethical issues concerning union and the employment of certain distinctive forms of language to describe unitive states points to a fruitful realm of comparative dynamics. ${ }^{6}$

Mystics make use of a variety of images and symbols, as well as distinctive expressions and forms of technical discourse, in their attempts to suggest through language what lies beyond language. Images of erotic love - the kiss, the embrace, the memory of encounter, even sexual intercourse - are favored ways of expressing mystical union.

Three images for mixing substances that originated in ancient philosophical writings are also popular among the mystics: the drop of water in a vat of wine, the bar of iron in fire, and air illuminated by the sun. Some images lend themselves more aptly to symbolizing the absorption that leads to mystical identity, such as the ocean, the desert, the mirror, the abyss, cloud and darkness, and the identical eye. As Meister Eckhart emphasizes: "The eye with which I see God is the same eye with which God sees me"7. Another powerful image for absorption is eating and being eaten. There are also distinctive linguistic expressions and strategies found across the three traditions: ecstatic identity pronouncements (especially in Islam); forms of dialectical language expressing fusion and indistinction; the language of the return to the pre-creational state; and reduplication discourses, often involving referential ambiguity, especially in dealing with pronouns signifying God and the human. ${ }^{8}$

Any attempt at a definition of mysticism must be deficient, not only on grounds of the broad spectrum of phenomena seen as mystical, but also on grounds of the historical transformations of the concept. First of all, it denotes the 'closing' (in Gk., muein) of the eyes and lips in the act of initiation into the Greek mystery religions, lest their secret knowledge

\footnotetext{
${ }^{4}$ Bernard MCGINN (2005), "Mystical union in Judaism, Christianity, and Islam", in Encyclopedia of Religion, Second Edition, Lindsay Jones, Editor in Chief, vol. 9: Mary • Ndembu Religion, Macmillan Reference USA, Thomson Gale, 2005, pp. 6334-6335.

5 Alois M. HAAS, "Unio mystica", in Historisches Worterbuch der Philosophie, edited by Joachim Ritter, Karlfried Grunder, and Gottfried Gabriel, vol. 11, cols. 176-179. Basel, Switzerland, 2001.

${ }^{6}$ Grace JANTZEN, “Chang' an Where Two Are to Become One': Mysticism and Monism”, in The Philosophy in Christianity, edited by Godfrey VESEY, Cambridge, U.K., 1989, pp. 147-166.

${ }^{7}$ Meister ECKHART, Despre omul nobil, cupa din care bea regale (About the noble man, the cup from which the king drinks), transl. and notes by Gabriel H. Decuble, Foreword by Anca Manolescu, Humanitas, București, 2007, p. 84.

${ }^{8}$ The unitive language is explicitly studied in: Bernard MCGINN. The Presence of God: A History of Western Christian Mysticism, New York, 3 vol.: 1991-2004.
} 
be betrayed. In Christianity, mysticism acquires the meaning of experiential knowledge of God (in Lat. cognitio Dei experimentalis) - especially, extraordinary 'experiences of God', understood as a special manifestation of grace, experiences occurring in rapture, visions, and ecstasy, whose purpose is a union with God in love and knowledge (unio mystica, Lat. 'mystical union').9' In Romanticism's veer from the Renaissance belief in reason and progress, mysticism became (1) a religion of emotion, of profound inner sensation, and (2) a pantheistic philosophical monism of union. The Romantic rediscovery of mysticism forms the image of mysticism in modern times, and fosters a modern individual piety. Mysticism becomes the expression of a spirituality joining East and West, a Philosophia Perennis (Lat. 'eternal philosophy') uniting humanity in a religion beyond institution and historical transformation, a content of all that is deepest and best in the religions. ${ }^{10}$

Very much allied with the difference between mystical uniting and mystical identity is the issue of annihilation. Many mystics have insisted that union-identity can only be found through annihilation of the self, but the meaning of annihilation is complex and open to a host of questions. What self is being annihilated: the created self or also a deeper, precreational self, found in God? Is the ego annihilation total and final or only in certain respects and for particular times and circumstances? Finally, is the annihilation in some way a mutual one in which both God and human lose themselves in some deeper reality? ${ }^{11}$

Furthermore when annihilation language is used in texts that stress mystical identity, it is often accompanied by strategies of qualification that must be taken into account to get the full measure of the meaning of annihilation. Some of these strategies are dialectical in the sense that they insist on the coexistence of indistinction and distinction in the relation between God and human - from one perspective union is total identity; from another, it coexists with an ongoing real difference between the two. Other qualifications are more perspectival, claiming that annihilation is essentially a matter of the consciousness of the mystic and not the structures of reality themselves. ${ }^{12}$

Romanticism's image of mysticism characterizes attempts at systematization on the part of early religious science. According to psychologist of religion William James (1902), mystical states are primarily pantheistic and optimistic; far from being knowable in words and concepts ('ineffability'), they are determined by feeling and knowledge, and therefore lead not to a 'faith' open to rational discussion; rather, they transmit subjective insights of unconditional value ('noetic quality'). James holds mystical states to be the root of all religion ${ }^{13}$. For religious scholar Rudolf Otto, the ultimate foundation of religion is mystical. Each individual religion is 'a priori' preceded by the primitive religious feeling of each individual, and the object of its relation (the numinous); these are the basic data of all religion, inexpressible because they are mystical.

\footnotetext{
${ }^{9}$ An acquaintance with Eastern teachings whose preferred theme is the one Being 'behind' all that is, in combination with Romantic medievalism, led to a universalization of the concept: it even became possible to speak of an a-religious mysticism.

${ }^{10}$ Cf. Steven FAnNIng, Mystics of the Christian Tradition, Routledge - Taylor \& Francis Group, London and New York, 2001, p. 111.

${ }^{11}$ Annihilation is not a simple or univocal category but is, rather, analogical, dialogical, and paradoxical.

12 Dan Merkur, Mystical Moments and Unitive Thinking, Albany, N.Y., 1999. The author argues for a new psychological approach to unitive thinking and contains a useful survey of modern theories of unio mystica.

${ }^{13}$ V. William JAMES, The Varieties of Religious Experience: A Study in Human Nature, New York, 1916, Seven Treasures Publications, 2009.
} 
The 'essence' of mysticism is held to lie in the preponderance of "irrational and numinous moments" as the "reference object of religious feeling." 14

The controversy over a 'universal mysticism': The common 'essence,' the coherent, transcultural 'nucleus' of all mysticism was seen by Rudolf Otto in the common subject of reference and in the common experience. Otto's concept of the Holy remained imprisoned in the Judeo-Christian image of God, so that his 'Western-Eastern mysticism' was actually onesided. R.C. Zaehner was also biased when it came to belief, since he undervalued monistic mysticism as not being in consonance with reality. Contemporary representatives of a 'universal mysticism' argue that the possibility of a common experience attaches to the structure of consciousness - something like a mind empty of thought and a psyche as an expansion of the inner world to the outside. ${ }^{15}$

In the late 1970s, Steven Katz began to present his ever-sharpening criticism of the notion of a 'universal mysticism.' Katz holds that insertion into a given culture and the interweaving of cultural variables and mystical experience are determinative: there is no 'pure,' immediate experience, or 'pure consciousness'. Instead, Weltanschauung and social environment have already generated the experience itself, and not only its description. Nothing can be experienced that is not already 'etched in.' Mysticism is conservative, and endorsing of tradition. ${ }^{16}$

On the other hand, another thing is to be stressed out: the narrow or the wider usage of the word "reason". In general the justification lies in the necessity of splitting things up and considering each part of the subject in turn. When the mystic says that his revelation is outside reason, he plainly does not mean that it is outside the sphere of the reasonable. No doubt he will urge that in the end the mystic life is the only reasonable one for a man to live. And this is better treated under the head of the relation between mysticism and ethics.

It has been claimed that mystical experience is altogether unconceptualizable, and that it is for this reason that it is said to be 'ineffable'. No doubt when the mystic says that his experience is "above" reason, he may mean both that it is outside the sphere of logic, and that it is beyond the reach of the understanding altogether; and no doubt the two statements are very closely connected, and may even imply each other. ${ }^{17}$

\footnotetext{
${ }^{14}$ Rudolf OтTо, West-östliche Mystik. Vergleich und Unterscheidung zur Wesensdeutung, Munich 1971 (1926) (Engl.: Mysticism East and West: An Analysis of the Nature of Mysticism, York, 1957); Typologizations in religious studies such as Friedrich Heiler's distinction (1919) between monistic (mystical) and dualistic (prophetical) religions, and Robert C. Zaehner's differentiation (1957) between monistic (natural) and theistic mysticism challenged Christian apologetics: Christianity is held to be characterized by its prophetical/ ethical commitment, while Eastern religions deny the world: redemption by grace plays out against a self-redemption, preferably by psycho-techniques. Cf. Annette WILKE, "Mysticism", in: The Brill Dictionary of Religion, p. 1280.

${ }^{15}$ Although this argument criticizes Otto and Zaehner, it, too, is based on the supposition that the experience itself is amorphous, and independent of cultural qualifications, and that the background in terms of a Weltanschauung qualifies only interpretation and enunciation: thus, it is only here that the multiplicity of mystical descriptions emerges in the distinct cultures. V. Frits STAAL, Exploring Mysticism A Methodological Essay,

Center for South and Southeast Asia Studies, UC Berkeley, Middlesex 1975.

${ }^{16}$ Jewish and Christian patterns of experience, for example, are begotten and marked by Jewish and Christian expositions of the Song of Solomon. For details: Steven T. KATZ (ed.), Mysticism and Religious Traditions, Oxford University Press, 1983.

${ }^{17}$ W.T. STACE, Mysticism and Philosophy, Macmillan \& Co ltd, London,1961, p. 252.
} 


\section{MYSTICAL UNION IN JUDAISM}

"Pre-Christian Judaism", asserted R. C. Zaehner, "is not only unmystical, it is antimystical [...] exclusively obsessed by the transcendent holiness of God and man's nothingness in face of him." God is a great and terrifying mystery in the Bible, and "not even in the Qur'an does this mysterium tremendum make itself so tremendously felt" ${ }^{\prime 18}$.

Judaism, Christianity and - probably to a lesser extent - Islam have all developed the idea of a personal God, so we tend to think that this ideal represents religion at its best. The personal God has helped monotheists to value the sacred and inalienable rights of the individual and to cultivate an appreciation of human personality. The Judaeo-Christian tradition has thus helped the West to acquire the liberal humanism it values so highly. These values were originally enshrined in a personal God who does everything that a human being does: he loves, judges, punishes, sees, hears, creates and destroys as we do. Yahweh began as a highly personalised deity with passionate human likes and dislikes. Later he became a symbol of transcendence, whose thoughts were not our thoughts and whose ways soared above our own as the heavens tower above the earth. The personal God reflects an important religious insight: that no supreme value can be less than human. Thus personalism has been an important and, for many, an indispensable stage of religious and moral development. The prophets of Israel attributed their own emotions and passions to God; Buddhists and Hindus had to include a personal devotion to avatars of the supreme reality. Christianity made a human person the center of the religious life in a way that was unique in the history of religion: it took the personalism inherent in Judaism to an extreme. It may be that without some degree of this kind of identification and empathy, religion cannot take root. ${ }^{19}$

The significance of unitive language in Jewish mystical traditions has been the subject of contention. Scholarly study of Judaism, born in the Enlightenment, relegated mysticism to the margins, seeking to demonstrate that Judaism was a rational form of moral monotheism. Even the celebrated scholar of Judaism, Gershom Scholem, who resurrected mysticism as central to Jewish history, sought to distinguish Jewish mysticism from Christian and Islamic forms, because its strict sense of the gulf between God and human made claims for mystical union, and especially mystical identity, suspect and secondary. ${ }^{20}$ Since the 1980s, however, new research by Moshe Idel $^{21}$, Bernard McGinn, and Rachel Elior has

\footnotetext{
${ }^{18}$ Though the edge is taken off this statement when a few pages later this author says of the Qur'an, "Not even in the Old Testament do you have such an over-mastering insight into Omnipotence." See R.C. ZAEHNER, At Sundry Times, Faber and Faber, London, 1958, pp. 15, 27, 171.

${ }^{19}$ Yet a personal God can become a grave liability. We can assume that he loves what we love and hates what we hate, endorsing our prejudices instead of compelling us to transcend them. When he seems to fail to prevent a catastrophe or even to desire a tragedy, he can seem callous and cruel. A facile belief that a disaster is the will of God can make us accept things that are fundamentally unacceptable. The very fact that, as a person, God has a gender is also limiting: it means that the sexuality of half the human race is sacralized at the expense of the female and can lead to a neurotic and inadequate imbalance in human sexual mores. A personal God can be dangerous, therefore. Instead of pulling us beyond our limitations, 'he' can encourage us to remain complacently within them; 'he' can make us as cruel, callous, self-satisfied and partial as 'he' seems to be. Instead of inspiring the compassion that should characterize all advanced religion, 'he' can encourage us to judge, condemn and marginalize. It seems, therefore, that the idea of a personal God can only be a stage in our religious development. The world religions all seem to have recognized this danger and have sought to transcend the personal conception of supreme reality. V. Karen ARMSTRONG, History of God, from Abraham to the present: the 4000-year Quest for God, Vintage U.K., Random House, 1999, pp. 243 f.

${ }^{20}$ Gershom ScHOLEM, Major Trends in Jewish Mysticism, New York, 1941. Classic work, though Scholem's view of the role of union in Judaism is contested. Also, Idem, The Messianic Idea in Judaism and Other Essays on Jewish Spirituality, New York, 1971. See the essay "Devekut, or Communion with God".

${ }^{21}$ Moshe IDEL, Kabbalah: New Perspectives, New Haven, Conn., 1988a.
} 
shown that unitive language, even expressions of mystical identity, is not at all foreign to Jewish mysticism, though it is late.

The earliest stages of Jewish mysticism represented by the Merkavah literature (c. second to tenth century a. Chr.) do not feature the language of union but concentrate on heavenly ascensions to a vision of the throne of God. Unitive language first appears in the mid-twelfth century in the early stages of Qabbalah. Though Jewish forms of unitive mysticism show important analogies to Christian and Muslim forms, the distinctive practices and linguistic character of Jewish mysticism, both in the various types of Qabbalah and in the later Hasidic mysticism, have their own hermeneutics. ${ }^{22}$

We start our demarche by appealing to the text of Deuteronomy 4:4 that states, "You who cleave to the Lord God are all alive this day" (cf. Dt. 10:20 and 13:5). The notion of "cleaving" (devekut) provided a biblical warrant for later unitive forms of Jewish mysticism, not only those of mystical uniting but also stronger connotations of mystical identity. Moshe Idel has suggested that unitive understandings of devekut and related terms, such as hitahed (uniting) and yihud (union), express two models of mystical union: a universalizing type in which the soul of the mystic becomes all-embracing by cleaving to the Universal Object ${ }^{23}$; and an annihilative-integrative model in which the mystic's ego is annihilated in order to be perfectly integrated into the divine realm. The qabbalistic and Hasidic mystics who used strong forms of mystical identity, like their Christian and Muslim counterparts, usually qualified their statements by insisting that identity with God was not total; the ego remains or returns, at least in some way. Similarly even the most powerful proponents of identity language never broke with Jewish halakhic practice or lapsed into an antinomian posture. ${ }^{24}$

Jewish unitive mystics. Among the earliest Jewish thinkers who spoke of mystical union was the mid-twelfth century philosopher Abraham ibn Ezra, who saw Moses' cleaving to God as a model for the soul's return to its primordial state of universality. This theme continued on in Qabbalah, for example in Ezra of Gerona (c. 1250), who held that the soul of a prophet ascends until it is united to the "supernal soul in a complete union" 25 , a formulation that seems to be influenced by Neoplatonic views. The most impressive work of Spanish Qabbalah, the Zohar, produced by mystical groups centered around Mosheh de Leon in the late thirteenth century, did not use extensive language of union, though the appearance of some unitive expressions (e.g., Zohar III.288a) became a proof text for later mystics. ${ }^{26}$

\footnotetext{
${ }^{22}$ Bernard MCGINN (2005), "Mystical union in Judaism, Christianity, and Islam", in Encyclopedia of Religion, vol. 9, p. 6339.

${ }^{23}$ Moshe IDEL, and Bernard MCGINN, eds., Mystical Union in Judaism, Christianity, and Islam: An Ecumenical Dialogue, 2d ed., New York, 1996.

${ }^{24}$ The only real heresy in the past eight centuries of Jewish history, that of Shabbetai Tsevi, was messianic in origin, not mystical.

25 Apud Moshe IDEL, Kabbalah: New Perspectives, p. 42.

${ }^{26}$ Apud Gershom SCHOLEM, Major Trends in Jewish Mysticism, p. 173. Other theosophical qabbalists, however, did employ considerable unitive language. For example, Isaac of Acre (c. 1300) understood cleaving as the means for attaining the gift of prophecy in the soul's ascent to union with the hidden godhead of Qabbalah, the Ein Sof. Commenting on Leviticus 19:24, he says that the years of the maturation of fruit trees mentioned in the text are to be understood as the advance of the soul through mystical stages until, "And in the fifth year', which refers to the 'Eiyn Sof which surrounds everything, this soul will cleave to the 'Eiyn Sof and will become total and universal, after she had been individual, due to her palace, while she was yet imprisoned in it, and she will become universal, because of her source" (Idel, 1988a, p. 48). This reference to attaining a pre-creational state echoes a theme found in contemporary Christianity and Islam. See: Moshe IDEL, Kabbalah: New Perspectives, p. 48 .
} 
But the most extreme formulations of identity mysticism in Qabbalah occur in the writing of Abraham Abulafia in the late thirteenth century. Abulafia's ecstatic form of Qabbalah, based upon practices of meditation and number manipulations, was fundamentally intellectualist. Like Plotinus, he envisaged an ascent to union with the Agent Intellect and finally to the Hidden God. Abulafia expresses this last stage in reduplicating language of fused pronouns comparable to some of the most extreme Muslim mystics:

"For now he is no longer separated from his Master, and behold he is his Master and his Master is he; for he is so intimately united with him, that he cannot by any means be separated from him, for he is he" 27

Speaking about the most important trend of Judaism's mystique, one can note that it is commonplace in contemporary scholarship to distinguish between two major typological trends of medieval Kabbalah, theosophic-theurgic and ecstatic-prophetic, a distinction that can be traced to nineteenth century scholarship though only developed in the twentieth century. This classification, however, runs the risk of oversimplification. Careful scrutiny of the relevant texts indicates that kabbalists whom we dub as 'theosophic' were capable of ecstatic experiences of a unitive nature and that kabbalists labeled 'ecstatic' presumed that esoteric gnosis imparted theosophic wisdom. Moreover, shared traditions about the secret names of God, and particularly the most sacred of these names, «YHWH», the sefirotic potencies as the means and end of mystical communion and the theurgical interpretation of ritual, bridge the presumed gap separating the proposed schools of Kabbalah. ${ }^{28}$

But unitive mysticism was at its strongest in some of the forms of Hasidic mysticism that began in Eastern Europe in the 18th century and that continue to flourish in the $21 \mathrm{st}$ century. The Hasidic mystics were deeply influenced by Qabbalah, but the qabbalists were generally more concerned with repairing the structures of the divine world, whereas the Hasidic masters stressed personal experiences of union. Amid a wealth of unitive statements found in Hasidic mysticism, the materials from the Habad movement, founded by Dov Ber (d. 1772), stand out. In a disciple of the maggid ${ }^{29}$, Shne'ur Zalman of Liadi (d. 1813), one finds extreme statements of annihilation and identity with the divine. In explaining the meaning of mystical interpenetration (hitkalelut), Shne'ur says:

"When man cleaves to God, it is very delightful for Him, and savorous for Him, so much so that He will swallow it into his heart, [...] as the corporeal throat swallows. And this is the true cleaving, as he becomes one substance with God in whom he was swallowed, without being separate [from God] to be considered as a distinct entity at all" ${ }^{\text {"30 }}$

Dov Ber of Lubavitch, Shne'ur's son, wrote Tract on Ecstasy, which carefully discriminated five levels of ecstatic progression in which the fourth level, one of annihilation, leads to the fifth form of ecstasy, "actual essential yehidah", which is "called "ecstasy of the whole essence', that is to say his whole being is so absorbed that nothing remains and he has no self-consciousness whatsoever" ${ }^{\prime 1}$

\footnotetext{
27 J. ABELSON, Jewish Mysticism, London: G. Bell and Sons, 1913. See: http://www.sacredtexts.com/jud/jm/index.htm

${ }^{28}$ But in spite of the legitimate challenge to the typological schematization, it is still useful to utilize these categories in providing a thumbnail sketch of the different schools of Kabbalah. V. Elliot R. WOLFSON, "Kabbalah", in: Kocku von STUCKRAD, ed., The Brill Dictionary of Religion, 1052.

${ }^{29}$ An itinerant Jewish preacher.

${ }^{30}$ Moshe IDEL, and Bernard MCGINN, eds., Mystical Union in Judaism, Christianity, and Islam: An Ecumenical Dialogue, p. 43.

${ }^{31}$ Louis JACOBS, trans. and ed., Dobh Baer of Lubavitch: “Tract on Ecstasy", London, 1963, pp. 136-139. Other Habad mystics, such as Aharon Halevi Horowitz of Staroselye (d. 1828), were even more daring in their
} 
Judaism has produced forms of mysticism so unlike any other and so variant among themselves that no common characteristic marks them all. At most we can say that they "commune" with one another, not that they share an identical spirit. ${ }^{32}$ The eschatological element most clearly appears in the earliest trend: the often gnostically influenced mythical speculation on Ezekiel's vision of the throne-chariot, the merkavah. Mysticism around this theme began in the first centuries a. Chr. It consisted of an attempt to ascend to the divine throne beyond the various intermediate spheres (the heikhalot). Except for its biblical starting point (first developed in the Ethiopic Apocalypse of Enoch), the impact of Gnostic pleroma mythology dominates this spiritual "throne world." But also the typically Hellenistic connection of mysticism and magic appears to have been strong. Merkavah mysticism declined after the seventh century, but enjoyed a steady revival in Italy in the ninth and tenth centuries, which, in turn, may have influenced medieval German Hasidism. ${ }^{33}$

It is hard to evaluate the precise 'mystical' significance of so popular a movement: Hasidism. Yet the intensive religious experience of its greatest writers leaves no doubt. Here particularly we should restrain ourselves from imposing too narrow limits on the term mystical. Hasidism may be more practical and certainly more social than earlier spiritual movements, but its emphasis upon a joyful spirit and moral living derives from a mystical source. Jewish mysticism shows an unparalleled variety of forms ranging from deep speculation to purely emotional experience. It consistently appeals to scriptural authority, yet no mystical movement ever strayed further from theological orthodoxy than late messianic Qabbalah. And still for all the variety of its forms and of the external influences to which it was exposed, Jewish mysticism unquestionably possesses a powerful unity of its own. In it the word dominates, and the often tragic experience of the present lives in constant expectation of the future. ${ }^{34}$

\section{3. "UNIO MYSTICA" IN CHRISTIANITY}

It has been common to discuss Eastern Orthodox Theology and mysticism separately from Western Catholic, but the Orthodox Church regards itself as catholic and universal, and the formal division of East and West did not come till the eleventh century when it was as much attacks from the Western Crusades as doctrinal differences that caused the split. Eastern Christians owed much to the Western Augustine or Gregory the Great, as Westerns were indebted to Eastern teachers like Athanasius and Basil.

The Greek qualifier mystikos is derived from the verb muein, meaning "to close the mouth or eyes." Ancient writers used the term in the sense of something hidden, as in the

claims for attaining mystical identity, but this is not the place to pursue mystical union in Habad, or among other Hasidic leaders, such as the famous Nahman of Bratslav (d. 1810).

${ }^{32}$ Gershom Scholem wisely embedded this irreducible diversity, reflective of a spiritual Diaspora, in the very title of his authoritative work Major Trends in Jewish Mysticism (1941).

33 Louis DUPRÉ (1987), "Mysticism" [first edition], in Encyclopedia of Religion, Second Edition, Lindsay JONES, editor, vol. 9, p. 6352.

${ }^{34}$ For details: Moshe IDEL, and Bernard MCGINN, eds., Mystical Union in Judaism, Christianity, and Islam: An Ecumenical Dialogue. 2d ed., New York, 1996; Moshe IDEL: Kabbalah: New Perspectives, New Haven, Conn., 1988; Also Idem, Studies in Ecstatic Kabbalah. Albany, N.Y., 1988; Also Idem, Hasidism: Between Ecstasy and Magic (Hasidismul intre extaz și magie, Hasefer, Bucuresti, 2001), Schocken, Ierusalim 2000; Rachel ELIOR, The Paradoxical Ascent to God: The Kabbalistic Theosophy of Habad Hasidism, Albany, N.Y., 1993. An introduction to Habad Hasidism and its language of union; Gershom SCHOLEM, Major Trends in Jewish Mysticism, New York, 1941. Also, Idem, The Messianic Idea in Judaism and Other Essays on Jewish Spirituality, New York, 1971. 
case of the mystery cults, but from the second century CE Christians adopted mystikos to signify the inner realities of their beliefs and practices. The word was most often used to describe the hidden spiritual meaning of the Bible, but it was also employed in speaking of the Sacraments and of the vision of God. Around the year 500 CE Pseudo-Dionysius coined the term "theologia mustike " to indicate the knowledge (or better, superknowledge) by which mystics attain God. ${ }^{35}$ And Pseudo-Dionysius was the first to use the term henosis mustike (Divine Names 2.9). ${ }^{36}$

If the term mystical union is rare, the reality of union with God is old in Christianity. The earliest Christian mystical system, that found in the Alexandrian exegete Origen (d. 254 $\mathrm{CE}$ ), already displays a rich teaching on the union between the loving soul and the Incarnate Logos, especially as found in the spiritual reading of the Song of Songs. Commenting on Song of Songs (2:10-13), Origen says: "For the Word of God would not otherwise say that the soul was his neighbor, did he not join himself to her and become one spirit with her."37 Here Origen is referencing a text from St. Paul (1 Cor. 6:17: "Whoever is joined to the Lord becomes one spirit with Him"), a passage that became the leitmotif for those forms of Christian mysticism that emphasize mystical uniting. For Origen and others, the soul burning with love for Christ is divinized by grace to enjoy a union of loving conformity with the Logos that introduces it to the delights of "mystical and ineffable contemplation."

The tenor of early Christian mysticism was determined by the New Testament and by trends in Hellenistic Judaism (especially Philo Judaeus's scriptural theology and the late Judaic meaning of gnōsis). A third factor, usually referred to as Neoplatonism, must be added. Yet that movement, though influential in the development of Christian spirituality, may be too restricted an account of its beginnings; Origen (and, to some extent, even Clement) had already developed a mystical theology of the image before Plotinus. It might be more accurate, then, to look to the entire philosophically Platonic, religiously syncretic, and generally Gnostic culture of Alexandria at the end of the second century. ${ }^{38}$

Controversy followed Origen's teachings long after his death. As with Clement, the progression of Christian theology in the fourth, fifth and sixth centuries left behind much of his theology and some of his Platonic base. He taught a first creation before the creation of the material world, the pre-existence of souls before their eventual bodily incarnation, the salvation of all beings and the subordination of Christ to God the Father ${ }^{39}$, while denying the

\footnotetext{
${ }^{35}$ The earliest uses of the term mystical union are found in the Spiritual Homilies ascribed to the Egyptian monk Macarius but actually written in Messalian circles in Syria in the late fourth century CE. See St. Macarius, Homilies, 10.2, 15.2, and 47.17.

${ }^{36}$ The Latin translators of the Dionysian corpus employed various terms for Dionysius's henosis, but use of unio mystica was rare, despite the many discussions of union found in the medieval and early modern periods. The term did emerge in some of the textbooks on mysticism of the sixteenth and seventeenth centuries. Cf. Michael A. SELls, Mystical Languages of Unsaying, Chicago, 1994. A challenging analysis of strong identity statements in Neoplatonism, Christianity, and Islam.

${ }^{37}$ Apud Michel DuPUY, "L'union a Dieu", in: Dictionnaire de spiritualite: Ascetique et mystique, doctrine et histoire, edited by Marcel Viller et al., vol. 11, Paris, 1992. See: J. Christopher KING, Origen on the Song of Songs as the Spirit of Scripture: The Bridegroom's Perfect Marriage-Song, Oxford Scholarship Online: February 2006.

38 Alexandru-Corneliu ARION, "Outlines of comparative view of Hindu and Christian Mysticism", in: International Journal of Theology, Philosophy and Science (IJTPS), No. 2, Year II, May, 2018, Valahia University Press, p. 70.

39 The fourth-century condemnations were a serious blow to his reputation, while his censure at the fifth ecumenical council in Constantinople in 553 left him posthumously branded as a heretic and many of his works were destroyed.
} 
resurrection of the physical body. Nonetheless, Origen's influence on Christian mysticism is immense. His allegorical interpretation of scriptures and his mystical view of the Song of Songs became standard among Christian spiritual writers, and, along with Clement of Alexandria, he was the founder of the exaltation of Christian asceticism as necessary preparation for mysticism that produced the monastic movement in the deserts of Egypt at the beginning of the fourth century. ${ }^{40}$

The view of Clement and Origen that Christianity existed on two levels - an inner, higher, mystical Christianity concerned with receiving the knowledge of God given only to those who had freed themselves of their passions (a state of apatheia, passionlessness), and ordinary Christianity concerned with instructing the masses in the moral teachings of the faith - continued to dominate the Church and attained its most extreme expression at the beginning of the fourth century with the appearance in Egypt of the Desert Fathers. By about the year 300 the Christian ideal of withdrawal from the world took a more literal expression when great numbers began to leave their homes and families and move out into the desert to live their lives in 'solitude'. Three types of monastics ("those who live alone") came to be found in the desert, hermits who truly lived apart from others, those who lived in laurae, collections of huts where the monks of the community lived alone but met together in a common church where the monastics would meet on Saturdays and Sundays for services, and cenobia, where the monks and nuns lived communally in barracks. ${ }^{41}$

St. Athanasius of Alexandria $(\dagger 373)$ marks an important step forward in the Christian understanding of the soul's way to God. In contrast to earlier forms of mystical theology based on the Platonist premise of the soul's natural kinship with God, Athanasius posits a great ontological gulf between God and all else - souls included. This gulf can only be crossed by God: man can only know God if God comes to him, comes down into the realm of corruption and death that man inhabits. And this he does in the Incarnation. Athanasius' understanding of the Incarnation and his understanding of the monastic life thus link up with each other. In the light of the Incarnation, those who desire to identify themselves with this God who comes down must follow the same movement. ${ }^{42}$ So, in Athanasius' Life of Antony, ${ }^{43}$ we read nothing of the soul's ascent to God in contemplation, but rather of its descent into the world given over to sin, a descent to the place of the demons there to do battle with them. And two centuries later, when the greatest of the monastic rules came to be written, that of St. Benedict, we find no word in it about contemplation.

And yet this anti-mystical strand in monasticism is only part of the story. The life of contemplation, the search for a sense of kinship with God, continues to call men, and so the two strands, what we might call mystical and anti-mystical, are woven together in the history of Christian monasticism and are the source of endless tensions. But, at the outset of this

\footnotetext{
${ }^{40}$ Steven FANNING, Mystics of the Christian Tradition, pp. $25 \mathrm{f}$.

${ }^{41}$ While the terms 'flight' and 'withdrawal' suggest that monastic life was an escape, it actually represented spiritual combat with oneself in a struggle to overcome the body and its passions and appetites in a life of asceticism, a term derived from the Greek word ascesis, 'discipline'. This was not asceticism for its own sake but rather for its reward, living in the presence of God and gaining knowledge of God, which was the life of the angels - a foretaste of the heavenly life. Cf. Johannes QUASTEN, Patrology, vol. 2, The Ante-Nicene Literature After Irenaeus, Westminster, MD, Newman Press, Utrecht-Antwerp, Spectrum Publishers, 1962.

${ }^{42}$ No longer will they be drawn upwards to holiness in ever greater likeness to the invisible God; now they will find themselves being drawn down into the material world with the Word made flesh. See Bernard McGINN, "Ocean and Desert as Symbols of Mystical Absorption in the Christian Tradition", in: Journal of Religion 74 (1994): 155-181.

${ }^{43}$ Life of St. Antony, 14, 67, 47: R. T. Meyer's translation in Ancient Christian Writers X, Longmans, 1950.
} 
history, we find them both embodied in a state of perfect development in one man, Evagrius of Pontus. ${ }^{44}$

Sometime in the years around 500, a writer, perhaps a monk in Syria, using the name of Dionysius the Areopagite (an Athenian converted to Christianity by St. Paul, mentioned in Acts 17.34) wrote a number of works which were regarded as quasi-apostolic and gained stature and authority very close to that of the Bible. Among the works of this author, now called Pseudo-Dionysius, was the very short tract Mystical Theology, presenting an essentially Platonic description of mysticism. To see "the mysterious things," one must pass beyond the intellect and reason and leave behind

"Everything perceived and understood, everything perceptible and understandable, all that is not and all that is, and, with your understanding laid aside, to strive upward as much as you can toward union with him who is beyond all being and knowledge. ${ }^{45}$

One must plunge into the truly mysterious darkness of unknowing. Here, renouncing all that the mind can conceive, wrapped entirely in the intangible and the invisible, he belongs completely to him who is beyond everything. Here, being neither oneself nor someone else, one is supremely united by a completely unknowing inactivity of all knowledge, and knows beyond the mind by knowing nothing. ${ }^{46}$

God, the author argued, was beyond all description, having "neither shape nor form, quality, quantity, or weight" and can "neither be seen nor be touched. It is neither perceived nor is it perceptible." One ascends to God, who "cannot be grasped by understanding", who "is beyond assertion and denial." The farther upward one flies, the more "our words are confined to the ideas we are capable of forming; so that now as we plunge into that darkness which is beyond intellect, we shall find ourselves not simply running short of words but actually speechless and unknowing."47

For Pseudo-Dionysius, one could reach God only by entering into a darkness of unknowing, for God transcends all human language and concepts. In this and in other extant works bearing his name, the author stresses the superiority of the apophatic method of describing God (that is, the way of negation, of stating what God is not) over the cataphatic (the way of affirming what God is), because the way of negation

"seems to me much more appropriate, for, as the secret and sacred tradition has instructed,

God is in no way like the things that have being and we have no knowledge at all of his incomprehensible and ineffable transcendence and invisibility". ${ }^{48}$

The mystical way in the East was distinguished by different writers. For the PseudoDionysius there were two ways, of affirmation and unknowing, and three ways of spiritual life: purgation, illumination and union. Isaac the Syrian, an ascetic writer of the seventh century, distinguished three stages on the way to union: penitence that is conversion of the will, purification that liberates from the passions, and perfection that is perfect love through grace. In Hesychasm, 'quietism', the mystical system taught by the monks of Mount Athos from the fourteenth century, emphasis was placed upon ascetic practices, quiet of body and mind, and attainment of the vision of the Uncreated Light of God. Breathing exercises were used which had some resemblance to Yoga, and concentration was fixed by repetition of the

\footnotetext{
${ }^{44}$ Andrew Louth, The Origins of the Christian Mystical Tradition. From Plato to Denys, 2nd edition, Oxford University Press Inc., New York, 2007, pp. 96-97.

${ }^{45}$ Pseudo-Dionysius, The Complete Works, 1.1., Colm Luibheid (trans.), New York and Mahwah, NJ, Paulist Press, 1987, p. 135.

${ }^{46}$ Ibid., 1.3, p. 137.

${ }^{47}$ Ibid., 5, p. 141. 102; Ibid., 3, p. 139.

${ }^{48}$ Celestial Hierarchy 2.3, in Pseudo-Dionysius, The Complete Works, p. 150.
} 
Jesus-prayer: 'Lord Jesus Christ, Son of God, have mercy on me'. There was considerable controversy over disciplines and doctrines, particularly over a distinction made between God's essence and his light, but for centuries Hesychasm was virtually identified with Orthodoxy. ${ }^{49}$

The leading hesychast Evagrius Pontus $(\dagger 599)$ insisted that the 'knowledge' that we had of God in prayer had nothing whatever to do with concepts or images but was an immediate experience of the divine which transcended these. It was important, therefore, for hesychasts to strip their souls naked: "When you are praying", he told his monks, "do not shape within yourself any image of the deity and do not let your mind be shaped by the impress of any form". Instead, they should "approach the Immaterial in an immaterial manner". 50 Evagrius was proposing a sort of Christian Yoga. This was not a process of reflection; indeed, 'prayer means the shedding of thought'. It was rather an intuitive apprehension of God. It will result in a sense of the unity of all things, a freedom from distraction and multiplicity, and the loss of ego - an experience that is clearly akin to that produced by contemplatives in non-theistic religions like Buddhism. By systematically weaning their minds away from their 'passions' - such as pride, greed, sadness or anger which tied them to the ego - hesychasts would transcend themselves and become deified like Jesus on Mount Tabor, transfigured by the divine 'energies'. 51

The goal of Orthodox Christian mysticism or spirituality is, however, the union of man with God in Christ. But since God is endless, the goal of union with Him, of our perfection, never corresponds to an end from which man can no longer advance. All Eastern Fathers agree that perfection has no end, but is an advance "from glory to glory" (2 Cor. 3:18), or the epektasis about which speaks St. Gregory of Nazianus. For the characterization of this union, the pretty bold term of deification or participation into divinity is used in the East ("partakers of divine nature", 2 Pet.1,4).

This destiny of man, who lives godly, but not by himself, but by participation - a distinction that avoids us to understand the union in pantheistic terms - is expressed by St. Athanasius' axiom: "God became man, so that man becomes God". The destiny of man in Christianity is to become a Christ by the likeness, that is, an adoptive son of God, or to become God not by identity but by participation in the divine nature. This union always retains its theandric character in Orthodox theology. ${ }^{52}$

\section{MYSTICAL UNION IN ISLAM}

What has become known as "Islam" emerged as the third religious movement within the Abrahamic tradition. On the seventeenth night of the month of Ramadan in $610 \mathrm{CE}$, during his month-long spiritual retreat to a cave on Mt. Hira, an angel (Gabriel) gave Muhammad a command "to recite" (iqra'). Enveloped by the overpowering presence of God,

\footnotetext{
${ }^{49}$ Vladimir LossKy, The Mystical Theology of the Eastern Church, J. Clarke, 1957, pp. 208 f.

${ }^{50}$ Evagrius Pontus, On Prayer, 67, apud Karen ARMSTRONG, History of God, from Abraham to the present: the 4000-year Quest for God, p. 255.

${ }^{51}$ Later hesychasts refined this exercise: contemplates should sit with head and shoulders bowed, looking towards their heart or navel. They should breathe ever more slowly in order to direct their attention inwards, to certain psychological foci like the heart. It was a rigorous discipline that must be used carefully; it could only be safely practised under an expert director. Gradually, like a Buddhist monk, the hesychast would find that he or she could set rational thoughts gently to one side, the imagery that thronged the mind would fade away and they would feel totally one with their prayer. Ibid., p. 256.

52 Dr. Alexandru-Corneliu ARION, Panteismul hinduist şi învățătura creștină despre Dumnezeu (Hindu pantheism and the Christian teaching on God), Enciclopedică Publishing House, Bucharest, 2010, pp. 437-438.
} 
Muhammad recited divinely inspired words. The Revelation makes a direct connection to previous revelations given to the Jews and Christians, and in fact presupposes them. The Quranic revelation finds its uniqueness in the fact that this was the first time in Arabia that the One God, "the God" - "al-Llāh" or "Allāh," had revealed himself in the people's own language. ${ }^{53}$

The root $s l m$ in Arabic means "to be in peace, to be an integral whole." From this root comes isläm, meaning "to surrender to God's law and thus to be an integral whole," and muslim, a person who so surrenders. It is important to note that two other key terms used in the Qur'ān with high frequency have similar root meanings: ìmān (from $a m n$ ), "to be safe and at peace with oneself," and taqwā (from wqy), "to protect or save." These definitions give us an insight into the most fundamental religious attitude of Islam: to maintain wholeness and proper order, as the opposite of disintegration, by accepting God's law. It is in this sense that the entire universe and its content are declared by the Qur'ān to be muslim, that is, endowed with order through obedience to God's law; but whereas nature obeys God's law automatically, humanity ought to obey it by choice. In keeping with this distinction, God's function is to integrate human personality, both individual and corporate: "Be not like those who forgot God, and [eventually] God caused them to forget themselves" (sürah 59:19). ${ }^{54}$

What is striking about Islam is the way in which strong forms of mystical identity emerged quite early in the development of the $S \bar{u} f \grave{\imath}$ tradition. In part this reflects the impact of the noted union hadìth (an extra- Qur'ānic divine statement):

"I became the hearing with which he hears, the seeing with which he sees, the hand with which he grasps, and the foot with which he walks." ${ }^{, 5}$

The emphasis on identity coexists along with highly developed forms of erotic union language. Through the absorption and transposition of themes from pre-Qur'ānic Arabian love poetry, the Süfì mystics, in both prose and verse, stand out among the most fervent proponents of the role of absolute, single-minded love in the pursuit of God, as such figures as Rābi'ah al-'Adawīyah (d. 810 CE), Jalāl al-Dīn Rūmī (d. 1273), and Fakhr al-Dīn 'Irāqī (d. 1289) demonstrate. ${ }^{56}$

Tawhìd, "to declare that God is one," is the central duty of all Muslims. The recognition that God alone is, that he is the sole agent, and that he alone can truly say "I" emphasizes that the absolute unity and simplicity of the transcendent creator also constitutes the immanent reality of all things, as the union hadith indicates. Annihilation and identity are central to Islamic belief and the mysticism based upon it.

What we know today under the rubric "Sūfissm" developed spontaneously within Islam as special religious and moral practices. The appellation "Sūfism" (tasawwuf) most likely stems from the Arabic term suf, meaning "wool," and was applied to those who practiced a life of self-surrender and who donned this coarse woolen attire of humility to set themselves off from a lifestyle of selfishness, comfort, and luxury. ${ }^{57}$ Perhaps the best

\footnotetext{
${ }^{53}$ See Karen Armstrong, Muhammad: A Biography of the Prophet, New York: HarperCollins, 1993, pp. 69 ff.

${ }^{54}$ Fazlur RAHMAN, (1987), "Islam: An Overview" [First Edition], in: Encyclopedia of Religion, Second Edition, Lindsay Jones, Editor in Chief, vol. 7: Iconography - Justin Martyr Religion, Macmillan Reference USA, Thomson Gale, 2005, pp. 4560-4561.

${ }^{55}$ V. 40 Hadith Qudsi, Hadith, 25. See: https://sunnah.com/qudsi40/25

${ }^{56}$ Reynold A. NiCHOLSON, The Mystics of Islam, 1914; reprint, Beirut, 1966, p. 68. Also: Studies in Islamic Mysticism, 1921; reprint, Cambridge, 1977.

57 This is the generally accepted derivation of the term, though already the tenth century Sūfi al-Qushayri (9861072) entertains other derivations. Some say the name "Sūfissm" comes from the Arabic word for purity, safa; others hold that it comes from the early disciples who, in their devotion, left their homes and surrounded the
} 
response was supplied by Abu Bakr al-Shibli, who was asked: "Why are the Sūfìs called by this name?" He replied: "It is because of the traces of the self that remain within them. If this were not the case, there would be no name attached to them!"58

Whatever etymology or origin we might ascribe to the term Sufism, it nevertheless depicts a profound religious and moral movement within Islam that internalizes the selfabandon to the One God on the model of the Prophet Muhammad. This mystical path has centered on serving God absolutely with the hope of experiencing Allah in a direct and personal manner. Such a practice intrinsically dissociated itself from knowing God through reason, from following ethical prescripts by rote, and from merely taking for granted the messages of the prophets. ${ }^{59}$ Beyond the ascetic and devotional practices of early Islam that characterized Sufism in the very beginning, by the ninth century, which begins the classical period of Sufism, Sufism was given to creative spiritual introspection and the examination of moral, legal, and philosophical issues inspired by lived experiences. ${ }^{60}$

For most of the Jewish mystics, the deeper meanings of the Torah are expressive of God's passionate love for humanity. The "Song of Songs," exemplifies this love, becoming not an inter-human ode, but a fervent, adoring love poem between God and human beings as lover and beloved. This intimate love relation between God and humanity is the mystical theme of the Quran for the Süfis. To evoke their intimate relation with God, many of the Arabic and Persian Sūfì writings are filled with such images adopted from the courtly literary tradition that are Islamic and pre-Islamic in origin. ${ }^{61}$

The essence of their doctrine is moral contrition and detachment of the mind from the "good things" of the world. But from its very early times, Sufism also had a strong devotional element. The love goal of God led to the doctrine of fana or "annihilation" (that is, of the human self in God). There were definitely Hellenistic Christian influences at work here. But the annihilation ideal was soon amended into "survival after annihilation," or (re)gaining of a new self, and this formula was given different interpretations. Most Sūfìs taught that, after the destruction of the human attributes (not the self), mortals acquire divine attributes (not the divine self) and "live in" them. The firm view of the orthodox and influential Süfis al-Junayd was that when a person sheds human attributes and these attributes undergo annihilation, that person comes to think that he or she has become God. But God soon gives that person the consciousness of otherness (not alienation!) from God, which is extremely painful and is only somewhat relieved by God's also giving the consolation that this is the highest state attainable by human beings. Yet there were also Sūfîs who, most probably under the influence of Hellenistic Christianity, believed in human transubstantiation into God. In 922, the Persian mystic and poet Mansur al-Hallāj, a representative of this school, was charged

Prophet on the bench (suffa) outside the mosque. See al-QUSHAYRI, Principles of Süfism, trans. B.R. von Schlegell, Berkeley, Calif.: Mizan Press, 1990, esp. pp.301-302.

${ }^{58}$ Cited by al-QuSHAYRI, Principles of Süfism, p. 306.

${ }^{59}$ See Sachiko MuratA and William C. CHITTICK, The Vision of Islam, St. Paul, Minn.: Paragon House, 1994, 238ff. However, this is a point contested by philosophers who are also mystics, e.g., Mulla Sadra. See Seyyed HOSSEIN NASR, Knowledge and the Sacred, Albany: SUNY Press, 1989

${ }^{60}$ See Carl W. ERnst, Words of Ecstasy in Süfism, Albany, N.Y., 1985, 4ff. Important study of the role of ecstatic utterances in Sūfîsm.

${ }^{61}$ Carl W. ERnst, Süfism: An Introduction to the Mystical Tradition of Islam, Shambhala, Boston \& London, 2011, pp. 154-61. 
with having uttered the blasphemous statement "I am God" (Ana 'I-Haqq), and was crucified in Baghdad. ${ }^{62}$

This example of such divergent interpretations of a fundamental doctrine should warn us that with Sufism we are dealing with a truly protean phenomenon: not only do interpretations differ, but experiences themselves must differ as well. However, under pressure from the 'ulamā', who refused to acknowledge any objective validity for the Sūfi experience, the Sūfìs formulated a doctrine of "spiritual stations" (maqāmāt) that adepts successively attained through their progressive spiritual itinerary. These stations are as objectifiable as any experience can be. Although the various schools have differed in the lists of these stations, they usually enumerate them as follows: detachment from the world (zuhd), patience (sabr), gratitude (shukr) for whatever God gives, love (hubb), and pleasure (rid̄a) with whatever God desires. ${ }^{63}$

After the violent death of al-Hallāj, another important doctrine of the dialectic of Sūfi experience was developed by orthodox Sūfiss. According to this doctrine, the Süfĩ alternates between two different types of spiritual states. One type is the experience of unity (where all multiplicity disappears) and of the inner reality. In this state the Sūfì is absent from the world and is "with God'; this is the state of "intoxication". The other state, i.e. that of "sobriety", occurs when the Süfì "returns" to multiplicity and is "with the world." Whereas many Sūfìs had earlier contended that "intoxication" is superior to "sobriety" and that, therefore, the saints are superior to the prophets (who are "with the world" and legislate for society), the orthodox Sūfìs now asserted the opposite, for the goodness of saints is limited to themselves, whereas the goodness of prophets is transitive, since they save the society as well as themselves. $^{64}$

Ibn al- 'Arabì's ( $† 1240)$ doctrine, known as Unity of Being teaches that everything is in one sense God and in another sense not-God. He holds that, given God, the transcendent, another factor that in itself is not describable "either as existent or as nonexistent" comes to play a crucial role in the unfolding of reality. This factor is neither God nor the world; it is a "third thing," but it is God with God and world with the world. It is the stuff of which both the attributes of God (for God as transcendent has no names and no attributes) and the content of the world are made. It is eternal with the eternal and temporal with the temporal; it does not exist partially and divided in things: the whole of it is God, and the whole of it is the world, and the whole of it is everything in the world. This "third thing" turns out finally to be the Perfect or Primordial Human Being (who is identified with the eternal, not the temporal, Muhammad), in whose mirror God sees himself and who sees himself in God's mirror. ${ }^{65}$

\footnotetext{
${ }^{62}$ Yet, a somewhat earlier mystic, al-Bistāmi (d. 874), who is said to have committed even graver blasphemies, was never touched by the law. See A. J. ARBERRY, Süfism: An Account of the Mystics of Islam, London, 1950, p. 145.

63 J. Spencer Trimingham, The Süfi Orders in Islam, New York, 1971, pp. 128-129.

${ }^{64}$ Fazlur RAHMAN, (1987), "Islam: An Overview" [First Edition], in: Encyclopedia of Religion, p. 4569. See also Anne-Marie SCHIMMEL, Mystical Dimensions of Islam, Chapel Hill, N. C., 1975. On the basis of this doctrine, al-Hallāj's famous statement was rationalized as "one uttered in a state of intoxication" and as such not to be taken at face value. But it was al-Ghazālī who effected a meaningful and enduring synthesis of Sūfĩ "innerism" and the orthodox belief system.

${ }^{65}$ This immanent God and Human Being are not only interdependent but are the obverse and converse of the same coin. There is little doubt that Ibn al-'Arabī represents a radical humanism, a veritable apotheosis of humanity. V. Muhammad IQBĀL, Reconstruction of Religious Thought in Islam, 1934; reprint, Lahore, 1960. For details: Remus RUS, Istoria filosofiei islamice (The History of Islamic Philosophy), Enciclopedică, București, 1994.
} 
It is to be noted the severe reaction against Sūfì excesses on the part of Ibn Taymīyah $^{66}$ in the 14 th century. It may be mentioned here that for Ibn Taymìyah the ultimate distinction between good and evil is absolutely necessary for any worthwhile religion that seeks to inculcate moral responsibility, and further, that this distinction is totally dependent upon belief in pure monotheism and the equally absolute distinction between man and God. He sets little value on the formal fact that a person belongs to the Muslim community; he evaluates all human beings on the scale of monotheism. Thus, as seen above, he regards pantheistic Sūfīs as being equivalent to polytheists. ${ }^{67}$

Going beyond all these contrasts, one can easily notice that while the mystical experiences described by the Sūfi mystics follow the same general pattern as those described by the mystics of other religions, there are elements in Sufism which make it of great interest to the student of mysticism. To the Süfi mystic self-renunciation is the essential thing if any real progress in the higher stages of the spiritual life is to be made. It is not, however, as in some mystics, a renunciation of the world, in the sense of turning one's back on the world. Rather, the Sūfi aspirant to union with God is bidden to plunge into the world, to merge himself in it, so that he may be able to understand what it truly is.

This process of self-mergence in the world is, however, different from that of the typical nature-mystic. For the Sūfĩ aspirant was taught that, in order to be able to see the world as it really is, the senses must be purified; the would-be mystic must free himself from egocentric judgement, his organs of perception must become clear and unclouded, his ' $\mathrm{I}$ hood' must be surrendered, his affections and will must be subjugated. Then, and only then, can his heart become the measure of Divinity; then, and only then, can the rhythm of his inner life be in tune with the Universal Life, with Spirit, with Self, with the 'Love which moves the sun and the other stars, ${ }^{68}$. We come to an end by appealing to few noticeable verses about the human soul and his relation to God, within Sūfi paradigm:

"Played by Thy Hand, the soul makes melody,

How art Thou in, and yet without the soul?

With Thee, my flame, I burn, without Thee, die;

How farest Thou without me, O my Whole? ....

Garden and mead are in His radiance dight,

His wine the rose adorns in lustre bright,

None in this world benighted He hath left,

His brand hath kindled in each heart a light., 69

\section{CONCLUSION}

In the monotheistic faiths the God of creation, revelation, and redemption is not a static and indifferent First Principle but a loving and all-knowing God, who creates humans whose likeness to Him consists precisely in their ability to know and to love. The various ways of expressing mystical union are intimately connected with the relation between

\footnotetext{
${ }^{66}$ He was a controversial medieval Sunni Muslim theologian, jurisconsult, logician, and reformer.

${ }^{67}$ Then come the Shī'ah and Christians because both consider a human being to be a divine incarnation; and last come Zoroastrians and the Mu'tazilah, since both posit two ultimate powers. See A. J. WENSINCK, The Muslim Creed: Its Genesis and Historical Development, 1932; reprint, NewYork, 1965.

${ }^{68}$ Because the mystic has become 'merged' in God, he is able to see the world as it is, that is, as God sees it. It then assumes a new complexion. Beauty and serenity are seen beneath all its apparent deformity and inhumanity. He hears in it a new music, sees a new color, and smells a new fragrance. God-mysticism and nature-mysticism coalesce. See F.C. HAPPOLD, Mysticism, a Study and an Anthology, Penguin Group, 1963, reprint 1990, pp. 249-250.

${ }^{69}$ Muhammad IQBĀL, “The soul and God”, trans. by A. J. Arberry, apud F.C. HAPPOLD, Mysticism, pp. 254-255.
} 
knowing and loving, both in the path to union and in its realization. Most mystics claim that both knowing and loving are necessary in the way to God, but many mystics stress the superiority of love, often expressed in highly erotic ways, whereas others conceive of union as attaining mental identity with the Divine Intellect. In unitive states some mystics contend that one reaches a higher divine way of knowing (gnōsis); other mystics see all loving and knowing, at least as most people conceive them, as abrogated when union or identity is attained. The variations found in Judaism, Christianity, and Islam on this essential problematic are too multiple to be easily characterized, but it is difficult to appreciate the dynamics of union unless one addresses the relation between unitive expressions and the roles of love and knowledge. ${ }^{70}$

Among the other persistent issues concerning the comparative dimensions of mystical union is that of the ethical implications of claims of having attained union-identity with God. If mystics think they have become in some sense one with God, what does this mean for their behavior and their relation to the wider community of faith? Does this indicate, for instance, that the ordinary religious practices, and perhaps even the moral code, no longer are binding on mystics? In both Christianity and Islam mystics, especially those who claimed identity with God, have been suspected of holding such views. ${ }^{71}$

Union, whether conceived of as the uniting of God and human or in a deeper way as some form of identity with God, has been a key feature of the mystical traditions of Judaism, Christianity, and Islam. Although direct links between the mysticisms of the three faiths have been relatively rare, the common dynamics of monotheistic attempts to express their consciousness of becoming one with God display analogies that invite further investigation and promise important contributions to ecumenical understanding. ${ }^{72}$

Whatever the path trod, the quest for complete and absolute self-mergence in Divinity is beset with danger. When the contemplative, to whatever religion he belongs, attains the state of the Unitive Life and undergoes the experiences which mark that state, he feels as though his individual self has ceased to exist, that it has been entirely lost in God. One need not go to the Sūfi mystics to find this. It is there in Ruysbroeck, in Eckhart, in St John of the Cross's 'each seems to be God', in St Paul's 'I live; yet not I, but Christ liveth in me'. It is at the heart of the Hindu 'Tat twam asi' (Thou art That) formulation. It can, however, easily result in an egocentric deification, which is not a loss of selfhood, but a glorification of the individual ego, and be expressed in exaggerated outbursts, such as: I am the One Real/ Glory be to me/ How great is my glory! ${ }^{73}$

"This mystical way of looking at things", says the philosopher J.N. Findlay, "enters into the experience of most men at many times". Rather than being a peculiar practice, possibly heretical, mysticism is but the fullest extension of the common way of humanity. On this view, "the so-called great mystics, people like Plotinus, Jalāl al-Dīn Rūmī, St Teresa and so on, are merely people who carry to the point of genius an absolutely normal, ordinary, indispensable side of human experience" ${ }^{, 74}$.

\footnotetext{
${ }^{70}$ Michael A. SELLS, Mystical Languages of Unsaying, Chicago, 1994, p. 198.

${ }^{71}$ These mystics were at times subject to persecution, imprisonment, and even death, as shown by the examples of al-Hallāj and 'Ayn al-Hamadhānī in Islam and Meister Eckhart, and Miguel de Molinos in Christianity.

72 Bernard MCGINN , "Mystical union in Judaism, Christianity, and Islam", in Encyclopedia of Religion, vol. 9, p. 6340 .

${ }_{73}^{7}$ F.C. HAPPOLD, Mysticism, a Study and an Anthology, p. 250.

${ }^{74}$ J. N. FInDLAY, Ascent to the Absolute, p. 164. apud Geoffrey PARRINDER, Mysticism in the World's Religions, Oneworld Publications, Oxford, 1995, p. 185.
} 


\section{BIBLIOGRAPHY:}

[1] Abelson, J., Jewish Mysticism, London: G. Bell and Sons, 1913.

[2] Abrahams, E.M., A comparative survey of Hindu, Christian \& Jewish Mysticism, Sri Satguru Publications, Indological and Oriental Publishers, a Division of Indian Books Centre, Delhi, India, 1995.

[3] Arberry, A. J., Sufism: An Account of the Mystics of Islam, London, 1950.

[4] Arion, Alexandru-Corneliu, Panteismul hinduist și învățătura creștină despre Dumnezeu (Hindu pantheism and the Christian teaching on God), Enciclopedică Publishing House, Bucharest, 2010.

[5] _ . "Outlines of comparative view of Hindu and Christian Mysticism", in: International Journal of Theology, Philosophy and Science (IJTPS), No. 2, Year II, May, 2018, Valahia University Press.

[6] Armstrong, Karen, History of God, from Abraham to the present: the 4000-year Quest for God, Vintage U.K., Random House, 1999.

[7] - Muhammad: A Biography of the Prophet, New York: HarperCollins, 1993.

[8] dupré, Louis, (1987), "Mysticism" [first edition], in Encyclopedia of Religion, Second Edition, Lindsay Jones, editor, vol. 9, Macmillan Reference USA, Thomson Gale, 2005.

[9] Dupuy, Michel, "L'union a Dieu", in: Dictionnaire de spiritualite: Ascetique et mystique, doctrine et histoire, edited by Marcel Viller et al., vol. 16, Paris, 1992.

[10] Eckhart, Meister, Despre omul nobil, cupa din care bea regale (About the noble man, the cup from which the king drinks), transl. and notes by Gabriel H. Decuble, Foreword by Anca Manolescu, Humanitas, București, 2007.

[11]Elior, Rachel, The Paradoxical Ascent to God: The Kabbalistic Theosophy of Habad Hasidism, Albany, N.Y., 1993.

[12]Ernst, Carl W., Sufism: An Introduction to the Mystical Tradition of Islam, Shambhala, Boston \& London, 2011.

[13] —. Words of Ecstasy in Sufism, Albany, N.Y., 1985.

[14]Fanning, Steven, Mystics of the Christian Tradition, Routledge - Taylor \& Francis Group, London and New York, 2001.

[15] Haas, Alois M., "Unio mystica", in Historisches Worterbuch der Philosophie, edited by Joachim Ritter, Karlfried Grunder, and Gottfried Gabriel, vol. 11, Basel, Switzerland, 2001.

[16] Happold, F.C., Mysticism, a Study and an Anthology, Penguin Group, 1963, reprint 1990.

[17] Idel, Moshe, Kabbalah: New Perspectives, New Haven, Conn., 1988.

[18] _- Hasidism: Between Ecstasy and Magic (Hasidismul între extaz și magie, Hasefer, Bucuresti, 2001), Schocken, Ierusalim, 2000.

[19]_. Studies in Ecstatic Kabbalah, Albany, N.Y., 1988.

[20] Idel, Moshe and McGinn, Bernard, eds., Mystical Union in Judaism, Christianity, and Islam: An Ecumenical Dialogue. 2d ed., New York, 1996.

[21] Iqbāl, Muhammad, Reconstruction of Religious Thought in Islam, 1934; reprint, Lahore, 1960.

[22] Jacobs, Louis, trans. and ed., Dobh Baer of Lubavitch: "Tract on Ecstasy", London, 1963.

[23] James, William, The Varieties of Religious Experience: A Study in Human Nature, New York, 1916, Seven Treasures Publications, 2009.

[24] Jantzen, Grace, “Chang' an Where Two Are to Become One': Mysticism and Monism”, in The Philosophy in Christianity, edited by Godfrey Vesey, Cambridge, U.K., 1989.

[25] Katz, Steven T. (ed.), Mysticism and Religious Traditions, Oxford University Press, 1983.

[26] King, J. Christopher, Origen on the Song of Songs as the Spirit of Scripture: The Bridegroom's Perfect Marriage-Song, Oxford Scholarship Online: February 2006.

[27] Lossky, Vladimir, The Mystical Theology of the Eastern Church, J. Clarke, 1957.

[28] Louth, Andrew, The Origins of the Christian Mystical Tradition. From Plato to Denys, 2nd edition, Oxford University Press Inc., New York, 2007.

[29] Mcginn, Bernard, "Mystical union in Judaism, Christianity, and Islam", in Encyclopedia of Religion, Second Edition, Lindsay Jones, Editor in Chief, vol. 9: Mary • Ndembu Religion, Macmillan Reference USA, Thomson Gale, 2005.

[30] Mcginn, Bernard, "Ocean and Desert as Symbols of Mystical Absorption in the Christian Tradition", in: Journal of Religion 74 (1994): 155-181.

[31] — . The Presence of God: A History of Western Christian Mysticism, New York, 3 vol.: 1991-2004.

[32] Merkur, Dan, Mystical Moments and Unitive Thinking, Albany, N.Y., 1999.

[33] Murata, Sachiko and Chittick, William C., The Vision of Islam, St. Paul, Minn.: Paragon House, 1994.

[34] Nasr, Seyyed Hossein, Knowledge and the Sacred, Albany: SUNY Press, 1989. 
[35] Nicholson, Reynold A., The Mystics of Islam, 1914; reprint, Beirut, 1966.

[36] Otto, Rudolf, West-östliche Mystik. Vergleich und Unterscheidung zur Wesensdeutung, Munich 1971 (Engl.: Mysticism East and West: An Analysis of the Nature of Mysticism, York, 1957.)

[37]Parrinder, Geoffrey, Mysticism in the World's Religions, Oneworld Publications, Oxford, 1995.

[38] Pseudo-Dionysius, The Complete Works, 1.1., Colm Luibheid (trans.), New York and Mahwah, NJ, Paulist Press, 1987.

[39]Quasten, Johannes, Patrology, vol. 2, The Ante-Nicene Literature After Irenaeus, Westminster, MD, Newman Press, Utrecht-Antwerp, Spectrum Publishers, 1962.

[40] al-Qushayri, Principles of Sufism, trans. B.R. von Schlegell, Berkeley, Calif.: Mizan Press, 1990.

[41] Rahman, Fazlur, (1987), "Islam: An Overview" [First Edition], in: Encyclopedia of Religion, Second Edition, Lindsay Jones, Editor in Chief, vol. 7: Iconography • Justin Martyr Religion, Macmillan Reference USA, Thomson Gale, 2005.

[42] Rus, Remus, Istoria filosofiei islamice (The History of Islamic Philosophy), Enciclopedică, București, 1994.

[43] Schimmel, Anne-Marie, Mystical Dimensions of Islam, Chapel Hill, N. C., 1975.

[44] Scholem, Gershom, Major Trends in Jewish Mysticism, New York, 1941.

[45] _ . The Messianic Idea in Judaism and Other Essays on Jewish Spirituality, New York, 1971.

[46] Sells, Michael A., Mystical Languages of Unsaying, Chicago, 1994.

[47] Staal, Frits, Exploring Mysticism A Methodological Essay, Center for South and Southeast Asia Studies, UC Berkeley, Middlesex 1975.

[48] Stace, W.T., Mysticism and Philosophy, Macmillan \& Co ltd, London, 1961.

[49] Trimingham, J. Spencer, The Süfi Orders in Islam, New York, 1971.

[50] Wensinck, A. J., The Muslim Creed: Its Genesis and Historical Development, 1932; reprint, NewYork, 1965.

[51] Wilke, Annette, "Mysticism”, in: The Brill Dictionary of Religion, edited by Kocku von Stuckrad, transl. from the German by Robert R. Barr, Koninklijke Brill NV, Leiden, Boston, 2006.

[52] Wolfson, Elliot R., "Kabbalah", in: Kocku von Stuckrad, ed., The Brill Dictionary of Religion.

[53]Zaehner, R.C., At Sundry Times, Faber and Faber, London, 1958.

[54] _ . Mysticism Sacred and Profane. An Inquiry into some varieties of Praeternatural Experience, Oxford, Clarendon Press, London, 1957. 